\title{
Effect of barium selenate injections on fertility of Pirlak ewes subjected to estrus synchronization during non-breeding season
}

\author{
MUSHAP KURU, OSMAN SOGUKPINAR*, MUSTAFA MAKAV**, NEBI CETIN*** \\ Department of Obstetrics and Gynecology, **Department of Physiology, Faculty of Veterinary Medicine, \\ Kafkas University, Kars 36100, Turkey \\ *Berat Veterinary Clinic, Afyon 03300, Turkey \\ ***Department of Obstetrics and Gynecology, Faculty of Veterinary Medicine, Yüzüncü Yıl University, Van 65090, Turkey
}

Kuru M., Sogukpinar O., Makav M., Cetin N.

Effect of barium selenate injections on fertility of Pirlak ewes subjected to estrus synchronization during non-breeding season

\section{Summary}

This study was aimed at determining the effect of barium selenate injections on the fertility of Pirlak ewes which had been subjected to progesterone-assisted estrus synchronization during the non-breeding season. A total of 150 Pirlak ewes between the ages of 2 and 5 years were used in the study. Sponges containing progesterone were inserted into the vaginas of the ewes for 11 (groups I and III) or 14 days (groups II and IV) for the purpose of estrus synchronization, and 500 IU equine chorionic gonadotropin (eCG) was administered on the day of sponge removal. In addition, barium selenate was injected s.c. immediately before estrus synchronization protocol in groups I and III. After the sponges had been removed, estrus was observed for four days. The ewes were mated with fertile rams. The pregnancy was determined by transrectal ultrasonography 30 days after mating. It was observed that the estrus rate, pregnancy rate, conception rate, lambing rate, twinning rate, and litter size were not statistically different $(\mathrm{P}>0.05)$ between the groups, but estrus onset was different $(\mathrm{P}<0.001)$. In conclusion, barium selenate injections did not affect the fertility parameters before progesterone-assisted synchronization was applied to the Pirlak ewes during the non-breeding season.

Keywords: barium selenate, Pirlak ewes, progesterone, synchronization

Small ruminants are seasonally polyestrous, and reproductive activities are related to the prolongation or shortening of daylight. In sheep and goats, sexual cycles start in the autumn months, when daylight is shortened, and these animals do not show estrus outside the breeding season. This period is called the anestrous season in small ruminants (14).

Progestagens are effectively used in the control and synchronization of estrus in sheep and goats. Negative and positive feed-back expressions of progestagens are used in estrus synchronization. Especially during the non-breeding season, equine chorionic gonadotropin (eCG) injections are performed in addition to progestagens applied for 12-14 $\mathrm{d}$ to obtain a high estrus rate and ovulation $(2,13,18)$. Ovulation can occur $48-72 \mathrm{~h}$ after eCG injections $(17,26)$. Of course, the success of this type of manipulation may depend on nutrition, body condition score, lactation, age, heat, light, and breed $(11,13)$.
Selenium (Se) and vitamin E (Vit E), which are reported to have different effects on reproduction, can be applied to maintain health of the reproductive flock. Especially in the case of sheep fed in pasture, it has been found that the combination of estrus synchronization with Se and Vit E supplementation may increase the fertility rate $(3,16)$. Se and Vit E protect biological membranes against oxidative degeneration and are an essential component of glutathione peroxidase (15, $20)$. It has been reported that intravaginal progesterone sources used for estrus synchronization in farm animals cause an increase in oxidative stress parameters (19, $21,25)$. Therefore, it has been reported that antioxidants can be applied in addition to the synchronization protocols in order to protect against oxidative damage and to increase fertility rates (25).

This study was aimed at determining the effect of barium selenate injections on fertility parameters, such as the estrus rate, onset of estrus, pregnancy rate, 
twinning rate, litter size and survival rate, for Pirlak ewes that were subjected to progesterone-based estrus synchronization during the non-breeding season.

\section{Material and methods}

This study was carried out with the approval of the Kafkas University's Ethics Committee for Animal Experiments (KAÜ-HADYEK-2016/068).

The study was carried out between February and March on a commercial farm located in Bolvadin in the Afyon province, Turkey. Bolvadin is situated at latitude $38^{\circ} 42^{\prime} 40^{\prime} \mathrm{N}$ and longitude $31^{\circ} 02^{\prime} 55^{\prime}$ 'E. The average altitude is 1016 meters above sea level.

Sheep were between day 60 and 70 of the postpartum period, and they were healthy on clinical examination. A total of 150 Pirlak ewes were used between the ages of 3-5 years. Their body condition scores (9) ranged from 2.5 to $3.0(1=$ extremely emaciated, $5=$ obese $)$ and their weight ranged from 40 to $50 \mathrm{~kg}$. A total of 9 fertile rams (Pirlak) were used in the study.

The ewes were fed with hay, alfalfa, and barley during synchronization protocols. Concentrated feed $(0.4 \mathrm{~kg}$ ewe $/$ day; barley, wheat, sunflower, cottonseed meal, corn, calcium carbonate, and dicalcium phosphate) was given during pregnancy. In the postpartum period, the ewes grazed during the day and were kept on the farm at night. Throughout the study, water and mineral salt lick were given ad libitum.

The ewes were randomly divided into the following four groups for estrus synchronization.

Group I ( $\mathrm{n}=50)$ : Barium selenate (B.V.P. Barium Selenate $^{\circledR}$, Interhas Animal Health, Turkey) was administered to the ewes at a dose of $1 \mathrm{mg} / \mathrm{kg}$ s.c. and sponges $(60 \mathrm{mg}$, medroxyprogesterone acetate, MAP, Esponjavet ${ }^{\mathbb{B}}$, HIPRA, Turkey) were inserted in the vagina with a special apparatus. The sponges stayed in the vagina for $11 \mathrm{~d}$. On d 11, i.m. $500 \mathrm{IU}$ eCG (Oviser ${ }^{\mathrm{B}}$, HIPRA, Turkey) was injected, and the sponge was removed.

Group II $(\mathrm{n}=25)$ : Sponges were inserted in the vagina with a special apparatus and stayed in the vagina for $11 \mathrm{~d}$. On d 11, i.m. 500 IU eCG were injected, and the sponges were removed.

Group III ( $n=50)$ : Barium selenate was injected at a dose of $1 \mathrm{mg} / \mathrm{kg}$ s.c., and sponges were inserted in the vagina. The sponges stayed in the vagina for $14 \mathrm{~d}$. On d 14, i.m. $500 \mathrm{IU}$ eCG were injected, and the sponges were removed.

Group IV $(\mathrm{n}=25)$ : Sponges were inserted in the vagina with a special apparatus and stayed in the vagina for $14 \mathrm{~d}$. On d 14, i.m. $500 \mathrm{IU}$ eCG were injected, and the sponges were removed.

Estrus detection was started $12 \mathrm{~h}$ after injection of eCG. Estrus signs were monitored four times a day for $15 \mathrm{~min}$. for a 4-day period. A teaser ram was introduced into the flock for estrus detection, and sheep in which estrus was detected were selected and separated from the flock. Those who were in estrus were mated with fertility-proven rams (18).

The pregnancy diagnosis was performed using transrectal ultrasonography (WELLD WED-3000V ${ }^{\circledR}$, Hasvet, Turkey) with a rectal probe $30 \mathrm{~d}$ after mating. Ultrasonographic examination was performed in the standing position, and ewes were recorded as pregnant when an embryo was detected (24).

In the study, reproductive characteristics, such as the estrus rate, onset of estrus, pregnancy rate, conception rate, lambing rate, twinning rate, litter size, and survival rate, were calculated by the following formulas:

Estrus onset $=$ time between sponge withdrawal and start of estrus

Estrus rate $(\%)=$ number of ewes showing estrus/number of ewes in the group $\times 100$

Pregnancy rate $(\%)=$ number of pregnant ewes/number of ewes in the group $\times 100$

Conception ratio $(\%)=$ number of pregnant ewes/number of mating ewes $\times 100$

Lambing rate $(\%)=$ number of ewes giving birth/number of pregnant ewes $\times 100$

Twinning rate $(\%)=$ number of ewes giving birth to twins/ number of pregnant ewes $\times 100$

Litter size $=$ total number of lambs/number of ewes giving birth

Survival rate $(\%)=$ number of living lambs/number of lambs born $\times 100$

In the groups, the onset of estrus was given as mean \pm SEM and evaluated by one-way ANOVA. The estrus rate, pregnancy rate, conception rate, lambing rate, and twinning rate were analyzed by Chi-square test. The survival rate was determined 30 days after parturition. In all analyses, the $\operatorname{SPSS}^{\circledR}$ (SPSS Version 18.0, Chicago, IL, USA) software package was used. Differences between the groups in terms of the observed fertility parameters were considered significant at $\mathrm{P} \leq 0.05$ levels.

\section{Results and discussion}

One ewe in group III and one in group IV were excluded from the study due to sponge dropping. Therefore, the fertility parameters were determined for 49 ewes in group III and 24 ewes in group IV (Tab. 1). During the study, premature birth or stillbirth did not occur.

There were no statistically significant differences in the estrus rate, pregnancy rate, conception rate, lambing rate, and twinning rate $(\mathrm{P}>0.05)$. The onset of estrus in the respective groups was $44.52 \pm 1.95,45.08$ $\pm 2.93,34.42 \pm 1.71$, and $33.74 \pm 2.37 \mathrm{~h}$, respectively. It was observed that the onset of estrus was similar for groups I and II $(\mathrm{P}=0.99)$ and for groups III and IV $(\mathrm{P}=0.99)$. It was also determined that estrus started earlier in groups III and IV than it did in groups I and II. This value was statistically significant $(\mathrm{P}<0.001)$. The litter size was not statistically different between the groups $(\mathrm{P}>0.05)$ and varied between 1.11 and 1.23. Among lambs followed for 1 month after birth, one lamb from group II and one from group III were dead (Tab. 1).

Most sheep breeds are seasonally polyestrous animals, and exogenous hormone applications are needed to induce estrus outside of the breeding season. Here, the main purpose is to increase the litter size and achieve economic gain. But there are many fac- 
Tab. 1. Some fertility parameters of the Pirlak ewes in which estrus synchronization with progesterone was performed during the non-breeding season

\begin{tabular}{|c|c|c|c|c|c|}
\hline Fertility parameters & Group I ( $n=50)$ & Group II $(n=25)$ & Group III ( $n=49)$ & Group IV ( $n=24)$ & $P$ value \\
\hline Estrus rate (\%) & $100(50 / 50)$ & $92(23 / 25)$ & $97.96(48 / 49)$ & $100(24 / 24)$ & ns \\
\hline Estrus onset (hour) & $44.52 \pm 1.95^{\mathrm{a}}$ & $45.08 \pm 2.93^{\mathrm{a}}$ & $34.42 \pm 1.71^{b}$ & $33.74 \pm 2.37^{b}$ & $<0.001$ \\
\hline Pregnancy rate (\%)* & $44(22 / 50)$ & $40(10 / 25)$ & $40.81(20 / 49)$ & $37.5(9 / 24)$ & ns \\
\hline Conception rate (\%) & $44(22 / 50)$ & $43.48(10 / 23)$ & $41.67(20 / 48)$ & $37.5(9 / 24)$ & ns \\
\hline Lambing rate (\%) & $100(22 / 22)$ & $100(10 / 10)$ & $95(19 / 20)$ & $100(9 / 9)$ & ns \\
\hline Twinning rate (\%) & $22.72(5 / 22)$ & $20(2 / 10)$ & $21.05(4 / 19)$ & $11.11(1 / 9)$ & ns \\
\hline Litter size & $1.23(27 / 22)$ & $1.20(12 / 10)$ & $1.21(23 / 19)$ & $1.11(10 / 9)$ & ns \\
\hline Survival rate (\%) & $100(27 / 27)$ & $91.67(11 / 12)$ & $95.65(22 / 23)$ & $100(10 / 10)$ & ns \\
\hline
\end{tabular}

Explanations: group I: barium selenate - 11 days MAP - eCG; group II: 11 days MAP - eCG; group III: barium selenate - 14 days MAP - eCG; group IV: 14 days MAP - eCG; MAP: medroxyprogesterone acetate, eCG: equine chorionic gonadotropin; *: the pregnancy rate 30 days after mating; ns: non-significant at $\mathrm{P} \leq 0.05$; $\mathrm{a}, \mathrm{b}$ : the difference between values with different letters in the same row is significant at the $\mathrm{P}$ value

tors that influence success in such applications (14, 27). Prolonged progesterone application (12-14 d) is possible especially in small ruminants during the non-breeding season, and estrus is stimulated (5). Vitamins or trace elements (such as Se) can be injected in addition to the hormones or mixed with the feed to enhance fertility properties $(7,15)$. In this study, the aim was to determine the effect of barium selenate injection on selected fertility characteristics in estrus stimulation and synchronization protocols by applying MAP for a long time (11-14 d) to Pirlak ewes in the non-breeding season. The results show that there were no statistically significant differences between the fertility parameters of the groups with and without barium selenate $(\mathrm{P}>0.05)$.

Synchronization studies using progestagens outside of the breeding season or transitional period in ewes found estrus rates of 77.8-88.9\% (9), 81.0-92.6\% (28), $86.6-93.3 \%$ (5), 95.8-96.2\% (22), and 86.7-100\% (15). In our study, the estrus rate was between $92 \%$ and $100 \%$. After the progesterone application was completed, the onset of estrus in synchronized ewes occurred 25.7-38.3 (17), 22.5-35.1 (9), 32.12-35.08 (10), 37.2-49.7 (18), and 46.3 (5) h later. The onset of estrus obtained in our research was compatible with the previous studies. Especially after a $14 \mathrm{~d}$ MAP application, estrus began earlier than it did after an $11 \mathrm{~d}$ MAP application $(\mathrm{P}<0.001)$. In a similar study, progesterone administration for 14 days was reported to have caused estrus sooner than progesterone treatment for $9 \mathrm{~d}$ or less (8).

Pregnancy rates reported in these studies were 41.3$-49.5 \%$ (4), 43.4-52.0\% (22), 56-84\% (23), 76\% (9), $82.6 \%(28), 76.9 \%(5)$, and $86.6 \%(6)$. The pregnancy rate obtained in our study was similar to that of Algan et al. (4) and Özyurtlu et al. (22), but lower than in the other studies. It was also found that barium selenate treatment did not affect the pregnancy rate. It is thought that one of the most important reasons for this difference is the difference between the races of sheep used in the studies. It has also been reported that high pregnancy rates in Pirlak ewes cannot be obtained by estrus synchronization performed out of the breeding season (4).

In this study, it was determined that the rate of lambing was high, varying between 95 and $100 \%$. Moreover, the proportion of twinning in different groups was $11.11-22.75 \%$, and the litter size varied from 1.11 to 1.23 . These findings were consistent with some studies $(4,12,15,28)$. But the twinning rate may vary depending on the breed. In our study groups, the survival rate of lambs ranged from 91.67 to $100 \%$. Abdelhadi et al. (1) and Özyurtlu et al. (22) reported that the lambs born after estrus synchronization had first-month survival rates of $91.7-100 \%$ and $92.3 \%$, respectively.

Koyuncu and Yerlikaya (15) obtained an estrus rate of $100 \%$, pregnancy rate of $96.7 \%$, and lambing rate of $100 \%$ after sodium selenate treatment during the breeding season. They reported that only the estrus rate was statistically different from that in the control group. Sánchez et al. (23) also added Se to diets of estrus-synchronized ewes. They found that Se administration reduced the pregnancy rate and lambing rate in the synchronized group. However, it was reported that there was a statistical difference between the group that was synchronized without the addition of Se to diet. Furthermore it is also suggested that Se may have a negative effect on some reproductive parameters. Köse et al. (16) reported that Se and Vit E injections, combined with estrus synchronization, did not have a positive effect on fertility parameters. In our study, barium selenate did not affect the reproductive parameters negatively, but it did not improve them, either, compared with the parameters in the groups without injection.

In conclusion, intravaginal MAP administration for 11 or $14 \mathrm{~d}$ did not change the fertility parameters, and affected only the onset of estrus in Pirlak ewes during the non-breeding season. In addition, barium selenate 
injection did not have a positive effect on reproductive parameters. It should be noted that selenium therapy in ewes may be beneficial and may increase fertility rates before estrus synchronization with progesterone in areas where selenium deficiency exists.

\section{References}

1.Abdelhadi S. A., Niar A. L., Smail N. L., Abdelhadi F. Z.: Struggle against perinatal lamb mortalities by using techniques of improvement and control of breeding on the level of Tiaret area (Algeria). J. Cell Anim. Biol. 2010, 4, 25-28.

2. Abecia J. A., Forcada F., Gonzalez-Bulnes A.: Hormonal control of reproduction in small ruminants. Anim. Reprod. Sci. 2012, 130, 173-179.

3. Afshari G., Hasanpoor A., Hagpanah H., Amoughli-Tabrizi B.: Seasonal variation of vitamin A and beta-carotene levels in Ghezel sheep. Turk. J. Vet. Anim. Sci. 2008, 32, 127-129.

4. Algan M. N., Uçar M., Yllmaz O.: Effect of Fluorogestone acetate and eCG on some reproductive parameters in lactating Pirlak ewes. VI. National Congress of Turkish Society of Veterinary Gynaecology, Fethiye, Turkey, October 15-18, 2015, p. 208-209.

5. Ataman M. B., Akoz M., Akman O.: Induction of synchronized oestrus in Akkaraman cross-bred ewes during breeding and anestrus seasons: The use of short-term and long-term progesterone treatments. Rev. Med. Vet. 2006, $50,257-260$

6. Ataman M. B., Aköz M., Findlk M., Saban E.: Induction of synchronized oestrus in Akkaraman Cross-Bred ewes treated with prostaglandine F2 alpha, norgestomet and sponges impregnated with different doses of fluorogestene acetate at the beginning transitional period. Kafkas Univ. Vet. Fak. Derg. 2009, $15,801-805$.

7. Balicka-Ramisz A., Pilarczyk B., Ramisz A., Wieczorek-Dabrowska M.: Effects of selenium administration on blood serum Se content and on selected reproductive characteristics of sheep. Arch. Tierzucht 2006, 2, 176-180.

8. Blaschi W., Lunardelli P. A., Marinho L. S., Max M. C., Santos G. M., SilvaSantos K. C., Melo-Sterza F. A., Baldassarre H., Rigo T. R., Seneda M. M.: Effects of progestagen exposure duration on estrus synchronization and conception rates of crossbreed ewes undergoing fixed time artificial insemination. J. Vet. Sci. 2014, 15, 433-437.

9. Dogan I., Nur Z.: Different estrous induction methods during the non-breeding season in Kivircik ewes. Vet. Med. Czech. 2006, 51, 133-138.

10. Dogruer G., Ergun Y., Karaca F., Saribay M. K., Ates C. T., Akoz M., Aydin I.: The effect of applications of eCG and PGF2 $\alpha$ at different times with FGA containing vaginal sponges on reproductive parameters in ewes at anestrous season. Eurasian J. Vet. Sci. 2015, 31, 158-162.

11. Fentoni L. S., Shackell G. H., Ramsay M. L., Dodds K. G., Reid P. J., Mcleodi $B$. J.: Influence of year, age, and geographical location on induced oestrus in ewes early in the breeding season. N.Z. J. Agric. Res. 1997, 40, 69-74.

12. Gabryszuk M., Klewiec J.: Effect of injecting 2-and 3-year-old ewes with selenium and selenium-vitamin E on reproduction and rearing of lamb. Small Ruminant Res. 2002, 43, 127-132.
13. Gordon I. (ed.): Controlled Reproduction in Sheep and Goats. CABI Publishing, Wallingford, United Kingdom 1997.

14. Kaçar C., Kaya S., Kuru M., Zonturlu A. K.: Contemporary methods for the control of reproduction in sheep and goats. Turkiye Klinikleri J. Vet. Sci. Obstet. Gynecol-Special Topics 2016, 2, 29-37.

15. Koyuncu M., Yerlikaya H.: Effect of selenium-vitamin E injections of ewes on reproduction and growth of their lambs. S. Afr. J. Anim. Sci. 2007, 37, 233-236.

16. Köse M., Kırbas M., Dursun S., Bayril T.: The effect of injections of $\beta$-carotene or vitamin E+ selenium on fertility in ewes in anestrus season. YYÜ Vet. Fak. Derg. 2013, 24, 83-86.

17. Kulaksız R., Daskın A., Dalcı T.: Some reproductive traits of ewes from different breeds following oestrus synchronisation by flugeston acetate-eCG during the breeding season. Atatürk University J. Vet. Sci. 2011, 6, 9-15.

18. Kulaksız R., Uçar Ö., Daşkın A.: Effects of FGA sponge and ovsynch based protocols on reproductive performance of fat-tailed ewes during the breeding season. Kafkas Univ. Vet. Fak. Derg. 2013, 19, 629-633.

19. Kuru M., Ögün M., Oral H., Kükürt A., Makav M., Kulaksız R.: The use of controlled internal drug release for synchronization augmented oxidative and nitrosative stress and leptin levels in Georgian goats. J. Cell. Neurosci. Oxid. Stress 2016, 8, 541-542.

20. Morgante M., Beghelli D., Pauselli M., Dall'Ara P., Capuccella M., Ranucci S.: Effect of administration of vitamin $E$ and selenium during the dry period on mammary health and milk cell counts in dairy ewes. J. Dairy Sci. 1999, 82, 623-631

21. Oral H., Öğ̈̈n M., Kuru M., Kaya S.: Evaluation of certain oxidative stress parameters in heifers that were administered short term PRID. Kafkas Univ. Vet. Fak. Derg. 2015, 21, 569-573.

22. Özyurtlu N., Köse M., Bayril T., Küçükaslan I.: Comparison of some reproductive traits of Zom and Awassi ewes induced estrous cycle during transition period. Dicle Üniv. Vet. Fak. Derg. 2016, 2, 67-72.

23. Sánchez J., Jiménez A., Regodón S., Andrés S.: Inhibitory effect of selenium supplementation on the reproductive performance in synchronized Merino Sheep at range conditions in a selenium-deficient area. Reprod. Dom. Anim. 2008, 43, 328-332.

24. Schrick F. N., Inskeep E. K.: Determination of early pregnancy in ewes utilizing transrectal ultrasonography. Theriogenology 1993, 40, 295-306.

25. Sönmez M., Bozkurt T., Türk G., Gür S., Kizil M., Yüce A.: The effect of vitamin E treatment during preovulatory period on reproductive performance of goats following estrous synchronization using intravaginal sponges. Anim. Reprod. Sci. 2009, 114, 183-192

26. Wildeus S.: Current concepts in synchronization of estrus: Sheep and goats. J. Anim. Sci. 2000, 77, 1-14.

27.Zarkawi M., Al-Merestani M. R., Wardeh M. F.: Induction of synchronized oestrus and early pregnancy diagnosis in Syrian Awassi ewes, outside the breeding season. Small Ruminanat Res. 1999, 33, 99-102.

28. Zonturlu A. K., Özyurtlu N., Kaçar C.: Effect of different doses PMSG on estrus synchronization and fertility in Awassi ewes synchronized with progesterone during the transition period. Kafkas Univ. Vet. Fak. Derg. 2011, 17, 125-129.

Corresponding author: Mushap KURU, DVM, PhD, Department of Obstetrics and Gynecology, Faculty of Veterinary Medicine, Kafkas University, Paşaçayırı Campus, Kars 36100, Turkey; e-mail: mushapkuru@hotmail.com 